\section{Obushenko T., Tolstopalova $\mathbf{N}$. Baranuk N.}

\title{
THE SOLVENT SUBLATION OF BROMOCRESOL GREEN FROM WATERS SOLUTIONS
}

Об’єктом дослідження є стічні води, забруднені барвниками. Наявні методи очищення стічних вод від барвників досить часто недосконалі, неефективні або ж відсутні. Це зумовлює необхідність розроблення та впровадження ефективних і недорогих у використанні та експлуатації технологій очищення від барвників. При очищенні стічних вод найбільша проблема - видалення барвників з розбавлених низькоконцентрованих розчинів. Для очищення таких стоків запропоновано флотоекстракцію. Цей метод заснований на комбінації методів флотації і екстракції, та на пропусканні газових бульбашок крізь водну фазу і винесенні речовини забрудника (сублату) в органічну фазу.

В ході дослідження використовувалися імітати стічних вод, забруднених аніонним барвником бромкрезоловим зеленим в інтервалі концентрацій 2-20 мг/дм³. Досліджено вплив деяких параметрів на ступінь вилучення барвника: вихідна концентрація барвника, тривалість флотоекстракиіі. Встановлено раціональні умови видалення барвника: Н 3-3,5, молярне співвідношення бромкрезоловий зелений - гексадецилпіридиній хлорид=1:1. Найефективніше видалення барвника забезпечується при використанні фільтру Шотта з діаметром пор 100 мкм, витраті повітря 110-120 см³/хв, тривалості процесу 10 хв. За иих умов ступінь видалення барвника складає 88-99\%.

Отримані результати підтверджують перспективність запропонованого методу для ефективного видалення барвників з низъкоконцентрованих водних розчинів. Метод має ряд переваг:

- можливість роботи з великими об'ємами водних об'єктів;

- активна речовина виноситься бульбашками газу і надходить у шар гідрофобної рідини без змішування фаз;

- процес не є рівноважним і не лімітується константою розподілу;

- неможливість утворення емульсій;

- багаторазове конщентрування іонів у невеликих об'ємах органічного розчинника;

- потребує невеликої кількості екстрагенту у порівнянні з рідинною екстракцією.

Ключові слова: флотоекстракція барвників, поверхнево-активні речовини, стічні води, бромкрезоловий зелений, гексадецилпіридиній хлорид.

\section{Introduction}

A large amount of sewage contains various dyes, which are toxic and dangerous to the environment. To such drains it is necessary to carry sewage waters of factories on which these dyes do, as well as effluents of the coloring departments of various industrial enterprises. According to some estimates, it is assumed that the loss of dyes during their production is about $1-2 \%$, and for active dyes $-4 \%$ of the produced volume. Probably, these losses are a consequence of the dissolution of the dyes in water used for their synthesis, the specific consumption of which at some enterprises reaches an average of $225 \mathrm{~m}^{3}$ of water for the production of 1 ton of dye. In the textile industry, the specific water consumption reaches $400 \mathrm{~m}^{3}$ per 1 ton of produced products, respectively, the volume of waste water increases to $50 \ldots 400 \mathrm{~m}^{3}$. Depending on the class of the dye, the kind of painted textile material, from 5 to $50 \%$ of the initial amount of the dye passes to the sewage. Therefore, it is not surprising that when discharging waste water into reservoirs without cleaning, the concentration of these pollutants significantly exceeds the maximum permissible standards $\left(0.05-0.25 \mathrm{mg} / \mathrm{dm}^{3}\right)$ [1]. Harmful substances along with sewage enter water bodies, worsen their sanitary condition and cause the need for special deep water treatment before its use for domestic and industrial needs. Industrial wastewater treatment is carried out at local or centralized treatment facilities, but they can't always cope with the task of water purification from this type of pollutants. Dyes are characterized by a complex chemical structure and therefore are not subject to biochemical degradation in aqueous systems. In this regard, the search for efficient ways of extracting dyes from wastewater is now topical.

\section{The object of research and its technological audit}

The object of research is wastewaters contaminated with dyes. Dyes form a large class of organic compounds, which are characterized by the presence of unsaturated bonds (chromophores), such as $-\mathrm{CC} \mathrm{C},-\mathrm{N}=\mathrm{NN}-$ and $-\mathrm{C} \equiv \mathrm{N}-$, responsible for coloring, as well as the functional groups responsible for their fixation on matter $-\mathrm{NH},-\mathrm{OH},-$ $\mathrm{COOH}$ and $-\mathrm{SO}_{3} \mathrm{H}$. World production of textile materials uses active dyes with high color characteristics and resistance to physical, chemical and physical and mechanical properties. Therefore, getting into the environment, dyes 
easily color the water and the environment, thereby creating an unfavorable aesthetic perception, worsening the organoleptic properties of water. In addition, dyes can also significantly affect the ability of photosynthesis in water bodies, reducing the intensity of light penetration and can also be toxic to some aquatic species of flora and fauna due to aromatic rings and chlorine substituents. This can lead to mass death of representatives of the water world, violation of self-purification processes, the health status of the reservoir, severe human poisoning. A large amount of sewage contains various dyes, which are toxic and dangerous to the environment. These include sewage of factories, on which these dyes are made, as well as paint shops of various industrial enterprises. One of the most problematic places is the removal of dyes from dilute solutions.

Bromocresol green is widely used in modern analytical chemistry with acid-base titration. During the chemical studies, it is possible to observe the color transition of the solution from light yellow to blue with a $\mathrm{pH}$ interval of 3.8 to 5.4. Due to its excellent chemical properties, this reagent is often used to accurately determine albumin in plasma or serum.

\section{The aim and objectives of research}

The aim of research is studying the pattern of removal of anionic dyes from model aqueous solutions by solvent sublation using the example of bromocresol green dye.

To achieve the aim, the following tasks are set:

1. To select a cationic surfactant and a solvent sublation agent for the bromocresol green dye.

2. To set the optimal conditions for the process.

\section{Research of existing solutions of the problem}

The existing methods of physico-chemical wastewater treatment from dyes can be divided into three main groups.

The first group of methods ensures the extraction of pollutants by transferring dyes to sediment or solvent sublation slime by sorption of metal hydroxides formed on the flakes of the reagent waste water treatment (coagulation, reagent pressure flotation, etc.). The drawbacks of this group include: a low purification degree, especially discoloration, the need to recycle the precipitation of water treatment and their dehydration.

The second group includes separative methods (sorption on active carbon and macropores of ion exchangers, reverse osmosis, ultrafiltration, etc.). These methods provide a high degree of wastewater treatment, but require preliminary mechanical and chemical treatment to remove insoluble impurities, complex in instrumentation, have a high cost of cleaning.

The third group unites destructive methods based on deep oxidation-reduction transformations initiated by various physicochemical processes, in particular oxidants $\left(\mathrm{O}_{2}, \mathrm{O}_{3}\right.$, $\mathrm{Cl}_{2}, \mathrm{H}_{2} \mathrm{O}_{2}$ ), ultraviolet and solar radiation, the Fenton method. In most cases, no precipitation forms during their realization, additional contaminants in the form of chloride, sulphate and other ions are not introduced into the treated water, however, when these methods are implemented, irrecoverable loss of valuable components occurs [1-3].

All this necessitates the development and implementation of efficient and at the same time inexpensive in the implementation and operation of technologies for wastewater treatment from dyes. The search for new, more sophisticated and economically expedient methods that make it possible not only to remove dyes from wastewater, but also to regenerate expensive components, is one of the main trends in the development of wastewater treatment technology.

Solvent sublation is technology that was first introduced as an improved method of ionic flotation, which eliminates the possibility of foaming. This method provides simultaneous separation and concentration and is effective in wastewater treatment from organic and inorganic pollutants $[4,5]$. This method is based on a combination of flotation and extraction methods, based on the transmission of gas bubbles through the aqueous phase and the removal of the pollutant substance (sublate) into the organic phase. In this case, the organic phase should be lighter than the aqueous phase, and not dissolve in it. In the solvent sublation process, surfactants are used, which play the role of collectors. Surfactants form with heavy metal ions in water-insoluble hydrophobic sublates, which bind to air bubbles and are taken out of the aqueous phase into the organic phase. Since the solvent sublation process takes a short time (15-20 $\mathrm{min})$, the organic phase, which must have a thickness of 7-10 mm, regardless of the geometry of the flotation column, does not have time to fully exhaust its capacity as an extractant. Therefore, the solvent sublation efficiency is not dependent on the distribution coefficient. A sublate, bubbled substance, can both dissolve in the organic layer, and form a suspension that is retained by wetting $[4,5]$.

The selective solvent sublation of two dyes, methyl orange and rhodamine $\mathrm{B}$ from dilute solutions at $\mathrm{pH} 10.5$ and hexadecyltrimethylammonium bromide as surfactant is studied in [6]. Isooctanol was used as an organic solvent. The ratio of separation of methyl orange from rhodamine $\mathrm{B}$ from equimolar aqueous solutions with nitrogen bubbles with a low flow rate $(5 \mathrm{ml} / \mathrm{min}$.) is very high and is 510 .

In [7] ion flotation and solvent sublation are used to remove another dye, the usual blue one from synthetic sewage. Hexadecyltrimethylammonium bromide is used as surfactant and paraffin oil - as an organic solvent. More than $98 \%$ of the dye is removed after 5 minutes of solvent sublation with a flow rate of gas bubbles of $150 \mathrm{ml} / \mathrm{min}$.

The authors of [8] consider the removal of the dye of bromophenol blue from an aqueous solution using hexadecylpyridinium chloride as surfactant. A high degree of removal of the dye (more than $95 \%$ ) by solvent sublation is observed after $10 \mathrm{~min}$, when isopentanol is used as the organic solvent and the gas flow rate is $75 \mathrm{ml} / \mathrm{min}$.

In [9], sodium dodecylbenzenesulfonate is used for solvent sublation of a methyl violet dye from an aqueous solution. Methyl violet is extracted to isopentanol. The stoichiometric amount of surfactant proved to be the most effective for removal of this dye (the molar ratio of the surfactant dye=1:1). In 10 minutes of solvent sublation, more than $97 \%$ of the dye is removed.

In study [10], solvent sublation of bromocresol green dye is investigated. Hexadecylpyridinium chloride is used as the surfactant. The dye complex from surfactant flew with nitrogen bubbles and was extracted to the organic phase - isooctanol. After 5 minutes, bubbling gas at a rate of $75 \mathrm{ml} / \mathrm{min}$, more than $99 \%$ recovery of bromocresol green is observed. 
In recent years, studies of solvent sublation have been conducted both in Ukraine and abroad [11-14]. So, taking into account the detrimental effect of dyes on flora and fauna and the imperfection of existing technologies with their removal, the solvent sublation method is proposed as an effective alternative. Despite the past achievements of scientists in the study of this technology, there are still a lot of unreviewed aspects and conflicting data concerning the solvent sublation of extracts of dyes, so it is worth further research on this topic.

\section{Methods of research}

Determination of the dye removal efficiency is studied depending on: type of organic solvent, initial dye concentration, surfactant molar ratio: dye, $\mathrm{pH}$ of the initial solution. As a surfactant, hexadecylpyridinium chloride is selected experimentally (for a number of known cationic surfactants). Surfactant together with the dye forms a hydrophobic complex, which interacts with the gas bubbles and rises to the interface between the phases «water - organic compound» and is absorbed by the organic phase.

The solvent sublation process is carried out in a cylindrical glass column $35 \mathrm{~mm}$ in diameter. The air from the compressor is fed through a porous glass partition. The gas flow rate is controlled by a rotameter. The initial concentration of the dye is $1-20 \mathrm{mg} / \mathrm{dm}^{3}$. The volume of the model solution is $300 \mathrm{~cm}^{3}$, the volume of the organic phase is $6-14 \mathrm{~cm}^{3}$. The solvent sublation process is at a constant residual concentration of the dye, which is determined by the photometric method on a single-beam scanning spectrophotometer Portlab 501 (UK). The $\mathrm{pH}$ adjustment is carried out with solutions of $\mathrm{NaOH}$ at a concentration of $0.1 \mathrm{~mol} / \mathrm{dm}^{3}$ and $\mathrm{HCl}$ at a concentration of $0.1 \mathrm{~mol} / \mathrm{dm}^{3}$ ( $\mathrm{pH}$ of the aqueous solutions is measured with a $\mathrm{pH}$-meter $\mathrm{pH}-150 \mathrm{MИ}$ ).

The measure of the solvent sublation efficiency is the indicator of the dye removal degree $\mathrm{X}, \%$.

\section{Research results}

Surfactant molecules are directly involved in the sublate formation and affect the degree of recovery, reducing the value of free surface energy at the interface between the organic and aqueous phases, and stabilize the surface of the bubbles. As a surfactant for bromocresol green, cationic surfactant hexadecylpyridinium chloride (HPC) is chosen.

As can be seen from the graph in Fig. 1, the best molar ratio of surfactant: dye is 1:1. At a lower concentration of the surfactant, the removal rate was slow and the residual concentration of the dye is greater due to the incomplete formation of the surfactant dye complex. However, when the ratio is greater than $1: 1$, the degree of removal also decreases due to competition on the surface of the bubble of excess surfactant ions with the surfactant dye complex.

When choosing the organic phase, it is necessary to consider the following features:

- organic phase should not mix with water;

- must not be dissolved in water;

- show the ability to stay on the water surface and not form emulsions;

- have a density in the range of $0.75-0.90 \mathrm{~g} / \mathrm{cm}^{3}$;

- should be non-volatile at room temperature.

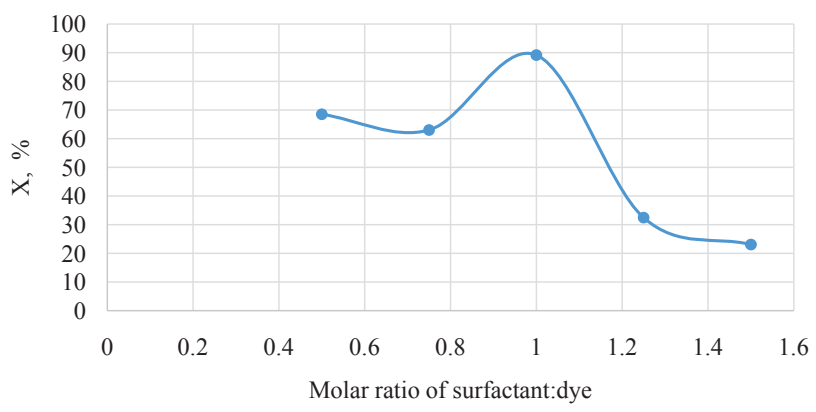

Fig. 1. Dependence of the dye removal degree on the molar ratio surfactant: dye

In general, the higher the efficiency of the process, the higher the solubility of the complex (dye-surfactant) in the organic solvent. The extractants: octanol, hexanol, butanol, n-amyl, isoamyl, isobutyl alcohols, butyl acetate, heptane (Fig. 2).

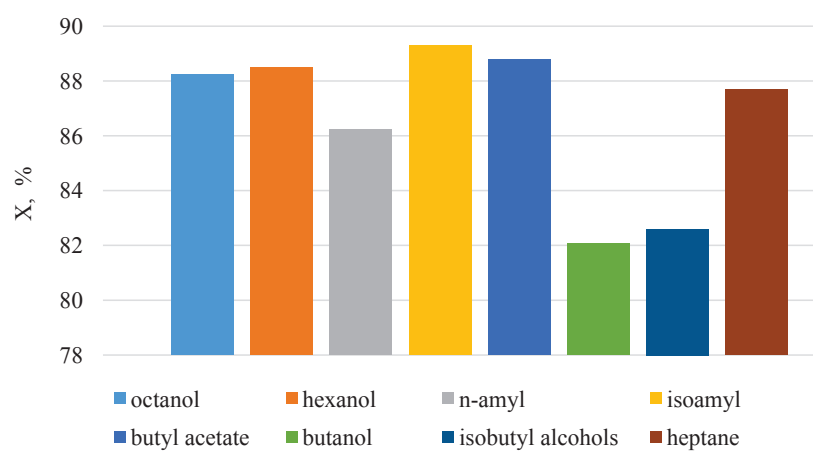

Fig. 2. Dependence of the solvent sublation efficiency on the extractant type

As can be seen from the graph in Fig. 2, the optimum extractant is isoamyl alcohol. When used, the degree of dye removal is $89.3 \%$. However, other extractants, such as octanol, hexanol, butyl acetate, provided a fairly high level of pollutant removal $(88.2 \%, 88.5 \%$ and $88.8 \%$, respectively).

At different $\mathrm{pH}$ values, surfactant and the dye can form various complexes that have different hydrophobicity and different solubilities in the organic phase. It is established (Fig. 3) that the removal efficiency of bromocresol green reaches its highest value in the $\mathrm{pH}$ range $3-3.5$ and is $87.5-89 \%$.

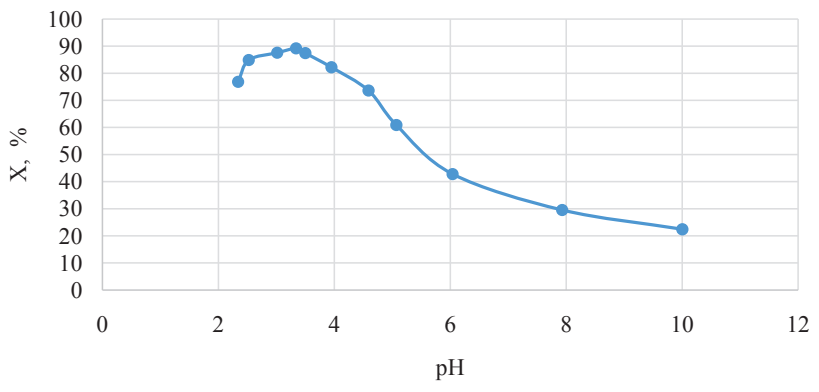

Fig. 3. Dependence of the dye solvent sublation on the $\mathrm{pH}$ of the aqueous phase

With a further increase in $\mathrm{pH}$ (from 4 to 6 ), a rapid drop in the degree of removal of the dye from 82 to $43 \%$ is observed. The subsequent increase in $\mathrm{pH}$ to a value 
of 10 also provides a reduction in removal efficiency of up to $22 \%$.

The degree of removal of bromocresol green dye is studied depending on the duration of the process. The experiments are carried out in the time interval 5-50 min (Fig. 4).

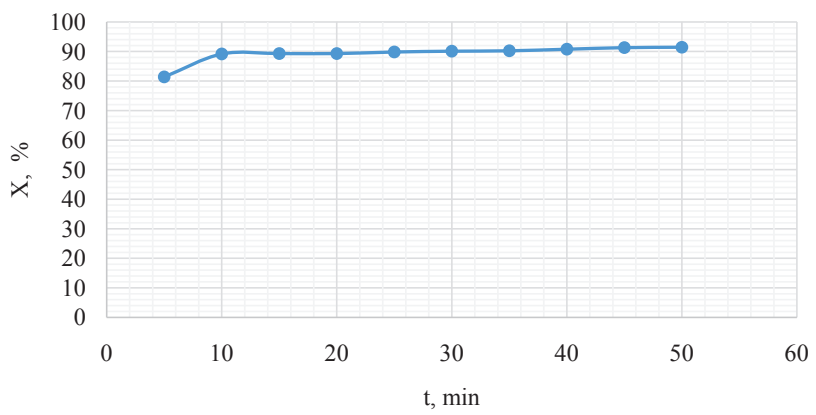

Fig. 4. Dependence of the dye removal degree on the solvent sublation duration

As can be seen from the graph in Fig. 4, more than $80 \%$ of the dye is removed within the first 5 minutes of the process. The rational time of solvent sublation for bromocresol green is 10 minutes, which provides $89 \%$ removal of the dye from water. With further process, the degree of removal is slightly increased.

The solvent sublation method requires bubbles of small size, surfactant and an organic solvent. Models and experimental results indicate that the bubble radius is one of the key parameters in the solvent sublation process. The diameter of the bubbles, used in practice, is about $100 \mu \mathrm{m}$. It is important to note that this agrees with the maximum bubble diameter for a total laminar regime equal to $130 \mu \mathrm{m}$ [4]. The process of removing the dye is studied depending on the size of the pores of the Schott filter and as a consequence of the size of the bubbles produced during the process. Exemplary dye removals are investigated using filters with a pore diameter of 40,100 and $160 \mu \mathrm{m}$ (Fig. 5).

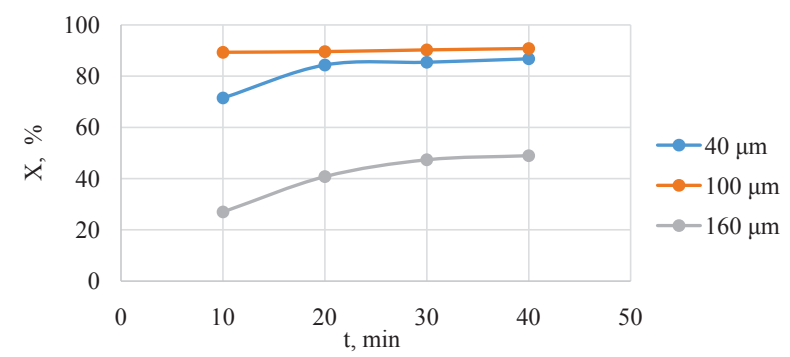

Fig. 5. Efficiency of dye removal depending on the pore size of the Schott filter

It is found that the most efficient removal of the dye is ensured by using a Schott filter with a pore diameter of $100 \mu \mathrm{m}$.

In solvent sublation, the volume of the organic phase does not affect the rate constant of the process. This is one of the most important advantages of solvent sublation over extraction. Most of the substance is transferred from the aqueous phase to the organic phase due to air bubbles crossing the interface, and not through the diffusion of matter through it. Then the amount of the transferred substance must depend only on the amount of air, crosses the phase boundary, and not on the number of phases. But it is very important to note that when the volume of the organic phase is too small, the phase boundary will break at even small gas consumption and the process will lose its effectiveness. The reverse of the mass transfer of matter from the organic phase to the aqueous phase begins and the volume of the organic phase becomes decisive (Fig. 6).

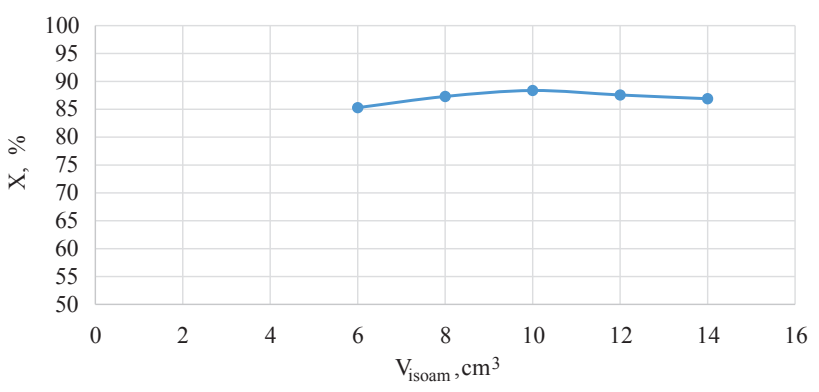

Fig. 6. Dependence of the dye removal degree on the volume of the organic phase

The obtained results indicate that the efficiency of the solvent sublation process of bromocresol green is rather weakly dependent on the extractant volume - the extraction rate varies in the range of 85.3...88.3\%. Effective purification is achieved when using $10 \mathrm{~cm}^{3}$ of isoamyl alcohol $-88.3 \%$, and the worst result is observed with an alcohol volume of $6 \mathrm{~cm}^{3}-85.3 \%$.

An indication that the gas flow rate is an important parameter in the solvent sublation process is the increase in the rate constant of the process with an increase in the flow velocity less than $80 \mathrm{~cm}^{3} / \mathrm{min}$. However, this dependence is not linear for large values. At high bubbling speeds, turbulization can occur on the solution surface, which leads to the risk of solubilization [2]. The rate of gas supply should be significantly less than in conventional ion flotation. This is necessary in order that the organic solvent layer is not ruptured. Undesirable is the breakthrough of a large amount of foam through this layer. If the gas feed rate is too high, some of the foam may pass through the solvent bed and form a foam layer above it. It is also possible that an increase in the gas velocity leads to an increase in the radius of the bubbles. This reduces the surface area per unit volume of gas and the residence time of bubbles in the water phase, since large bubbles have large lifting forces. But, despite this, it is established that an increase in the airflow through the column improves the intensity of the solvent sublation process, but only when the bubble sizes remain small.

The dependence of the removal efficiency of bromocresol green on the air flow in the range $75 \ldots 140 \mathrm{~cm}^{3} / \mathrm{min}$ is investigated (Fig. 7). It is revealed that the removal of the dye is most efficient at an air flow rate of $140 \mathrm{~cm}^{3} / \mathrm{min}$ and is $91.7 \%$ in 10 minutes. However, such gas flow intensity, as well as its further increase, causes a slight rupture of the organic phase, which can lead to repeated contamination of the treated water. Therefore, it is more rational to carry out the process at an air flow rate in the range of $110-120 \mathrm{~cm}^{3} / \mathrm{min}$. This ensures a high degree of purification (up to $90 \%$ ) and does not cause destruction of the extractant layer, and, therefore, eliminates the possibility of re-contamination of water. 
The influence of the bromocresol green initial dye concentration on the solvent sublation efficiency is studied (Fig. 8).

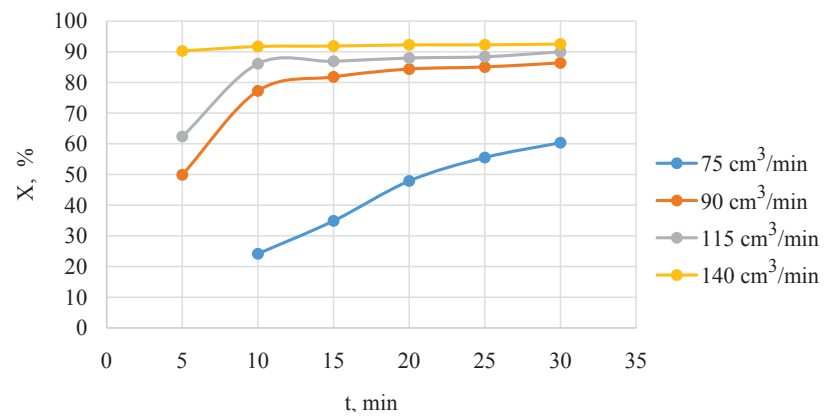

Fig. 7. Effect of gas consumption on the dye removal degree

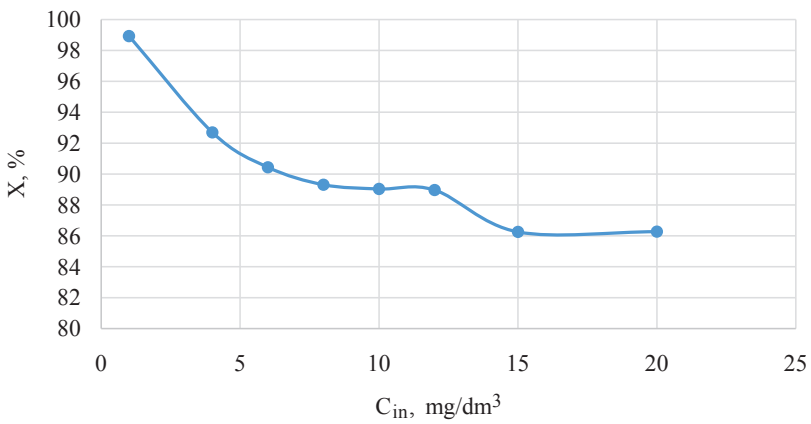

Fig. 8. Dependence of purification efficiency on the initial concentration of the dye

As can be seen from Fig. 8, a decrease in the concentration of the initial material provides an increase in the dye removal degree, and vice versa. Thus, with an initial bromocresol green concentration of $1 \mathrm{mg} / \mathrm{dm}^{3}$, purification is achieved up to $99 \%$, and at a concentration of $20 \mathrm{mg} / \mathrm{dm}^{3}$, the purification rate is reduced to $86 \%$.

\section{SWOT analysis of research results}

Strengths. The solvent sublation process has the following main advantages:

- active substance is carried out by gas bubbles and enters the upper layer of the hydrophobic liquid without mixing the phases. Thus, the separation process provides substantial selectivity, potentially greater than other solvent sublation processes. In addition, in solvent sublation, equilibrium is not achieved in the main part of the system, but only at the interface between the aqueous and organic phases, since the mass transfer process is strongly enhanced by bubble mass transfer. Consequently, the solvent sublation process isn't limited by the equilibrium constant, as a result, the efficiency of extraction of trace amounts of pollutants can theoretically reach $100 \%$;

- extraction degree in the solvent sublation process isn't dependent on the ratio of the volumes of the aqueous and organic phases;

- absence of phase mixing, that is, the formation of an emulsion is almost impossible in this case, except for the formation of an emulsion of water in an organic solvent, however such an emulsion isn't stable;

- simplicity of technological registration of process: there are no rigid modes of the control of temperatures or pressures, the equipment is simple in execution, there are no moving details;

- removed substance is in the organic phase, it fa-

cilitates its further processing.

Weaknesses. The main weaknesses of the method are low productivity in comparison with flotation due to a small gas flow rate, it does not destroy the upper layer of organic liquid in the distribution device. However, this assertion in some cases is controversial, since unlike the flotation process, sublate can be instantly extracted and dissolved in the liquid layer during the flotation process, it does not mix with water. This allows the use of large gas costs. Also, the increase in productivity is due to the reduction in the size of gas bubbles, which can be achieved, for example, when using the principle of pressure flotation in the solvent sublation process.

The negative influence of mixing during the solvent sublation process partially facilitates the design of the apparatus. In addition, the substance withdrawn need not necessarily dissolve well in the organic solvent, it is sufficient and just good wettability.

Opportunities. The proposed method provides a sufficient level of wastewater treatment from dyes. It can also be used in local wastewater treatment systems with the subsequent return of water to the process. This will ensure a reduction in spending on water consumption, discharge of sewage into water bodies, and will also limit the release of harmful substances into the environment. The features of solvent sublation allow to regenerate extractant and surfactant.

Threats. The difficulties of introducing the proposed method in the industry are due to the lack of a method for solvent sublation choosing. For the most effective extraction of pollutants, it is necessary to select the right surfactant. In addition, the range of surfactant is limited and the cost is quite high. Rational process conditions make it possible to increase the efficiency of solvent sublation and reduce the surfactant cost.

\section{Conclusions}

1. For solvent sublation of the dye of bromocresol green in the concentration range of $2-20 \mathrm{mg} / \mathrm{m}^{3}$ from aqueous solutions, a cationic surfactant, hexadecylpyridinium chloride and a solvent sublation agent (isoamyl alcohol) have been experimentally selected.

2. The rational conditions for removing the dye are established: $\mathrm{pH}$ 3-3.5, molar ratio bromocresol greenhexadecylpyridinium chloride=1:1. Effective removal of the dye is ensured by using a Schott filter with a pore diameter of $100 \mu \mathrm{m}$, an air flow rate of $110-120 \mathrm{~cm}^{3} / \mathrm{min}$, duration - $10 \mathrm{~min}$. Under these conditions, the dye removal degree is $88-99 \%$. The obtained results confirm the prospects of the proposed method for the effective removal of dyes from low-concentration aqueous solutions.

\section{References}

1. Nesterova L. A., Saribekov G. S. Efficiency of Use of Turnaround Systems of Water Consumption at the Textile Enterprises // Eastern-European Journal of Enterprise Technologies. 2010 Vol. 4, No. 8 (46). P. 25-28. URL: http://journals.uran.ua/ eejet/article/view/3022 (Last accessed: 10.03.2018).

2. Forgacs E., Cserha T., Oros G. Removal of synthetic dyes from wastewaters: a review // Environment International. 2004 Vol. 30, No. 7. P. 953-971. doi:10.1016/j.envint.2004.02.001 
3. Leskiv H. Z. Ochyshchennia stichnykh vod vid barvnykiv shliakhom adsorbtsii na pryrodnykh dyspersnykh sorbentakh: Abstract's PhD thesis. Lviv: Natsionalnyi universytet «Lvivska politekhnika», 2008. 20 p.

4. Lu Y., Zhu X. Solvent sublation: theory and application // Separation \& Purification Reviews. 2001. Vol. 30, No. 2. P. 157-189. doi:10.1081/spm-100108158

5. Bi P., Dong H., Don, J. The recent progress of solvent sublation // Journal of Chromatography A. 2010. Vol. 1217, No. 16. P. 2716-2725. doi:10.1016/j.chroma.2009.11.020

6. Caragay A. B., Karger B. L. Use of rate phenomena in solvent sublation separation of methyl orange and rhodamine B // Analytical Chemistry. 1966. Vol. 38, No. 4. P. 652-654. doi:10.1021/ ac60236a040

7. Horng J. Y., Huang S. D. Removal of organic dye (direct blue) from synthetic wastewater by adsorptive bubble separation techniques // Environmental Science \& Technology. 1993. Vol. 27, No. 6. P. 1169-1175. doi:10.1021/es00043a017

8. Lu Y., Wang Y., Zhu X. The removal of bromophenol blue from water by solvent sublation // Separation Science and Technology. 2001. Vol. 36, No. 16. P. 3763-3776. doi:10.1081/ ss-100108361

9. Lu Y., Zhu X., Peng Y. The removal of methyl violet from water by solvent sublation // Separation Science and Technology. 2003. Vol. 38, No. 6. P. 1385-1398. doi:10.1081/ss-120018815

10. Studies on the removal of bromocresol green from water by solvent sublation / Lu Y. et al. // Separation Science and Technology. 2007. Vol. 42, No. 8. P. 1901-1911. doi:10.1080/01496390601174398

11. The kinetics and thermodynamics of surfactants in solvent sublation / Lu Y. et al. // Fresenius' Journal of Analytical
Chemistry. 2001. Vol. 370, No. 8. P. 1071-1076. doi:10.1007/ s002160100914

12. Wastewater treatment from toxic metals by flotoextraction Obushenko T. I. et al. // Journal of Water Chemistry and Technology. 2008. Vol. 30, No. 4. P. 241-245. doi:10.3103/ s1063455x08040073

13. Teoretychni zasady ta praktychne zastosuvannia flotoekstraktsyy: ohliad / Astrelin I. M. et al. // Voda i vodoochysni tekhnolohii. 2013. No. 3. P. 3-23.

14. Thermodynamic Studies of Bromphenol Blue Removal from Water Using Solvent Sublation / Obushenko T. et al. // Chemistry \& Chemical Technology. 2016. Vol. 10, No. 4. P. 515-518. doi:10.23939/chcht10.04.515

Obushenko Tetjana, Senior Lecturer, Department of Inorganic Substances, Water Purification and General Chemical Technology, National Technical University of Ukraine «Igor Sikorsky Kyiv Polytechnic Institute», Ukraine, ORCID: http://orcid.org/0000-0003-0731-0370

Tolstopalova Nataliia, PhD, Associate Professor, Department of Inorganic Substances, Water Purification and General Chemical Technology, National Technical University of Ukraine «Igor Sikorsky Kyiv Polytechnic Institute», Ukraine, ORCID: http://orcid.org/00000002-7240-5344

Baranuk Nadiya, Department of Inorganic Substances, Water Purification and General Chemical Technology, National Technical University of Ukraine «Igor Sikorsky Kyiv Polytechnic Institute», Ukraine, e-mail: kiissld@gmail.com, ORCID: https://orcid.org/00000002-2288-1377 